\title{
KAJIAN KERUSAKAN LINGKUNGAN KARST SEBAGAI DASAR PELESTARIAN SUMBERDAYA AIR (KASUS DI DAS BRIBIN HULU KABUPATEN GUNUNGKIDUL DAERAH ISTIMEWA YOGYAKARTA)
}

\author{
Raras Endarto ${ }^{1}$, Totok Gunawan ${ }^{2}$ dan Eko Haryono ${ }^{3}$
}

Fakultas Geografi Universitas Gadjah Mada, Yogyakarta, Indonesia ${ }^{1,2,3}$

rarasendartogeo@gmail.com

Diterima : Juni 2014; Direvisi: Agustus 2014.; Dipubikasikan: Maret 2015

\begin{abstract}
ABSTRAK Sumberdaya airtanah di Kabupaten Gunungkidul identik dengan sistem bawah tanah Bribin (DAS Bribin). Bendung Bribin 1, Bribin 2, dan Seropan berada di Desa Dadapayu Kecamatan Semanu yang dimanfaatkan untuk mencukupi kebutuhan sebagian penduduk di Kabupaten Gunungkidul. Keberadaan DAS Bribin yang sangat penting bagi kelangsungan dan kesejahteraan penduduk harus dikelola kelestariannya. Pengelolaan lingkungan guna tercapainya kelestarian sumberdaya air ditekankan pada bagian imbuhan air, yaitu DAS Bribin bagian Hulu. Identifikasi tingkat kerusakan di DAS Bribin Hulu menjadi salah satu hal yang mendesak karena daerah tersebut merupakan media pemasok sungai bawah tanah bendung Bribin, Baron, dan Seropan yang dimanfaatkan untuk kebutuhan penduduk. Tingkat kerusakan karst yang dinilai berdasarkan Morfologi berbasis cekungan/SubDAS. Penelitian ini dilakukan dengan menggunakan pengamatan uji lapangan dan studi literatur terkait dengan kondisi daerah penelitian. Mempertimbangkan parameter kerusakan karst, meliputi perubahan moroflogi akibat penambangan, keberadaan outlet cekungan, tutupan vegetasi, kondisi mataair, kondisi gua, dan keberadaan bangunan di atas permukaan karst dilakukan penilaian tingkat kerusakan karst. Secara administratif tingkat kerusakan karst sangat tinggi berada di Desa Kenteng, Karangasem, dan Desa Bedoyo seluas 922,27 Ha. Adapun tingkat kerusakan karst tinggi berada di Desa Ponjong, Desa Sawahan, dan Desa Sumbergiri seluas 9.424,24 Ha. Tingginya tingkat kerusakan diantaranya akibat adanya penambangan yang besar, keberadaaan mataair, keberadaan bangunan diatas permukaan karst. Upaya strategi pelestarian dan pengelolaan dilakukan dengan berbasis karakteristik karst dan berbasis kewilayahan. Strategi kebijakan pengelolan karst berbasis karakteristik karst ditekan pada kenampakan permukaan (eksokarst). Strategi kebijakan pengelolaan karst berbasis kewilayahan merupakan rencana pengelolaan kawasan karst secara menyeluruh. Pengelolaan sumberdaya air erat kaitannya dengan keberadaan komponen karst (eksokarst), meliputi pengelolaan mataair, telaga, gua, dan bukit karst menjadi upaya penting dalam pengelolaan sumberdaya air. Pengelolaan berbasis kewilayahan mempertimbangkan beberapa faktor, diantaranya adalah keberadaannya (morfologi), konservasi kehutanan, dan arahan peruntukan fungsi.
\end{abstract}

Kata kunci: karst; kerusakan; pengelolaan sumberdaya air

\begin{abstract}
Groundwater resources in Gunung Kidul Regency synonymous with underground system Bribin (Bribin watershed). Reservoir Bribin 1, Bribin 2, and Seropan located in the Dadapayu village Semanu Sub-District utilize to comply needs of population in Gunung Kidul Regency. Existance of Bribin Watershed is very important for continuance and welfare of population which must be managed sustainability. Environmental management in order to achieve sustainability of water resources was emphasized on water recharge, namely Bribin Watershed of upstream section. Identification extent of damage in Bribin Watershed into one of urgency things because the area as underground supplier into reservoir river of Bribin, Baron, and Seropan was utilized for the needs of population. Extent damage of karst is assessed based on morphology of karst basin. This research was conducted using field observations and literature studies related to condition os study area. Considered of karst damage parameters, includes morphology change caused by mining, existance outlet basin, land cover, condition of springs, caves, and existance of building over the karst surface must be conducted assessment in extent of damage. Administratively, extent of damage karst is very high located in Kenteng, Karangasem, and Bedoyo Village, area of 922.27 hectares. The high levels of extent of damage karst is Ponjong, Sawahan, Sumbergiri Village, area of 9424.24 hectares. The high levels of extent of damage karst among others, existance of great mining, springs, and building over the karst surface. Efforts conservation and management strategies commits based on characteristic karst and regional. Karst management policy strategies based on characteristic karst was pressed in surface appearace(eksokarst). Karst management policy strategies based on regional are management karst area plan overall. Water resources management is related to existence of karst component (eksokarst), include management of springs,
\end{abstract}


reservoir, caves and karst hills into an important effort of water resources. Management based on regionally considers several factors, among others, existance of morphology, forest conservation, and landing of design function.

Keywords: karst; damage; management of water resources.

\section{PENDAHULUAN}

Sumberdaya airtanah di Kabupaten Gunungkidul identik dengan sistem bawah tanah Bribin (DAS Bribin). Bendung Bribin 1, dan Bribin 2, berada di Desa Dadapayu Kecamatan Semanu yang dimanfaatkan untuk mencukupi kebutuhan sebagian penduduk di Kabupaten Gunungkidul. Keberadaan DAS Bribin yang sangat penting bagi kelangsungan dan kesejahteraan penduduk harus dikelola kelestariannya.

Kelestarian lingkungan di DAS Bribin Hulu memiliki kecenderungan mengalami kerusakan. Rusaknya lingkungan dapat terjadi akibat dari proses solusional itu sendiri dan perubahan pemanfaatan lahan (aktivitas manusia). Upaya pengelolaan kelestarian sistem bawah tanah Bribin adalah menjaga dan melakukan konservasi di DAS Bribin Hulu. DAS Bribin Hulu memiliki sistem aliran bawah permukaan yang meliputi sebagian besar di Kecamatan Ponjong dan sebagian kecil kecamatan-kecamatan disekitarnya. DAS Bribin Hulu diindikasikan cenderung mengalami kerusakan lingkungan akibat pertambangan dan tingkat kesejahteraan penduduk yang rendah.

Berdasarkan pada kondisi biogeofisik dan peran aktivitas penduduk di DAS Bribin Hulu, maka perlu dilakukan kajian yang komprehensif dalam identifikasi karakteristik, tingkat kerusakan, dan strategi pengelolaan karst. Oleh karena itu, maka dirumuskan permasalahan penelitian sebagai berikut: (1) bagaimana karakteristik karst di DAS Bribin Hulu?; (2) bagaimana tingkat kerusakan karst di DAS Bribin Hulu?; (3) Bagaimana strategi pengelolaan lingkungan karst untuk tercapainya pelestarian sumberdaya air ?. Tujuan dari penelitian ini diantaranya adalah : (1) mengkaji kondisi karakteristik karst di DAS Bribin Hulu; (2) menganalis tingkat kerusakan karst di DAS Bribin Hulu; (3) menyusun strategi pengelolaan lingkungan karst dalam upaya pelestarian sumberdaya air.

\section{Proses Karstifikasi}

Proses pembentukan bentuklahan karst yang paling dominan adalah pelarutan. Pada prinsipnya yang dimaksud dengan karstifikasi adalah proses-proses yang menyebabkan berkembangnya topografi karst. Proses karstifikasi pada batugamping diawali oleh larutnya karbon dioksida $\left(\mathrm{CO}_{2}\right)$ di dalam air membentuk $\mathrm{H}_{2} \mathrm{CO}_{3}$ (Haryono dan Adji, 2004). Ada dua hal pokok yang harus ada dalam proses pelarutan tersebut, yaitu unsur pelarut dan materi yang terlarut. Unsur pelarut utama tersebut adalah air, sedangkan materi terlarut adalah batuan dari jenis batuan karbonat. Potensi pelarutan batu karbonat sangat tinggi, hal ini dikarenakan Indonesia terletak di sekitar garis ekuator dan memiliki iklim tropis.

\section{Sumberdaya Air}

Sumberdaya air adalah air, sumber air, dan daya air yang terkandung didalamnya (UU No.7 2004 tentang Sumber Daya Air). Airtanah merupakan komponen dari suatu daur hidrologi yang melibatkan berbagai aspek, baik biogeofisikkimia, ekonomi, politik, maupun sosial budaya yang menentukan keberadaan airtanah di suatu daerah. Airtanah merupakan sumber air utama untuk memenuhi hajat hidup orang banyak. airtanah di kawasan karst berkembang menjadi sistem aliran bawah permukaan (sungai bawah tanah). Namun, eksploitasi yang berlebihan dapat menimbulkan berbagai dampak negatif.

\section{Kerusakan Lingkungan Kawasan Karst}

Kerusakan lingkungan kawasan karst identik dengan pertambangan, ekstensifikasi pertanian, penebangan hutan, dan utamanya perubahan penggunaan lahan. Pertambangan merupakan penyumbang kerusakan terberat di kawasan karst dan dibutuhkan waktu yang relatif lama dalam perlakuan konservasi. Menambang di kawasan karst memiliki pengaruh berkurangnya daya simpan atau daya tampung batugamping terhadap air hujan, lintasan air dapat berubah atau berpindah tempat, sumber-sumber airpun juga akan berkurangluahnya (Ko, 1997).

\section{METODE PENELITIAN}

Penelitian ini dilakukan dengan menggunaakan pengamatan uji lapangan dan studi literatur terkait dengan kondisi daerah penelitian. Berdasarkan uji lapangan dan studi literatur diperoleh penelitian yang mendasarkan pada pendekatan kualitatif dan kuantitatif. Pendekatan kualitatif diperoleh dari fenomena gambaran naratif dandiskripsi tekstual, yang mendasarkan pada inventarisasi kondisi lapangan.

Lokasi titik sampel pengamatan pada kegiatan lapangan ditentukan dengan pertimbangan keberadaan gua, mataair, luweng/ponor, telaga, dan kenampakan morfologi yang dianggap memberikan informasi penting. Fokus utama lokasi sampel terbagi menjadi area didasarkan pada unit satuan pemetaan di daerah tangkapan air pada mataair dan telaga berbasis SubDAS (Cekungan). Unit satuan pemetaan yang digunakan diperoleh dengan mengoverlay peta Topografi, peta eksokarst, dan peta geologi. Tingkat kerusakan lingkungan diklasifikasikan menjadi 5 klas, 
yaitu: sangat rendah, rendah, sedang, tinggi, dan sangat tinggi. Klasifikasi tingkat kerusakan lingkungan karst diperoleh dari pembobotan skoring didasarkan pada indikator komponen bio-geofisik-kimia dan komponen sosekbud.

Basis strategi pengelolaan lingkungan karst dalam pelestarian sumberdaya air selain tingkat kerusakan, juga mempertimbangkan arahan fungsi kawasan, morfologi, dan konservasi eksisting yang telah dilakukan oleh pemerintah dan masyarakat. Pertimbangan ketiga aspek/parameter tersebut didasari oleh pentingnya tepat gunanya terapan strategi pengelolaan, sehingga mampu mengikuti upaya pengelolaan lingkungan yang telah ada. Keempat aspek/parameter tersebut dilakukan overlay untuk memperoleh peta arahan pengelolaan karst, sebagaimana ditunjukan dalam Gambar 2.

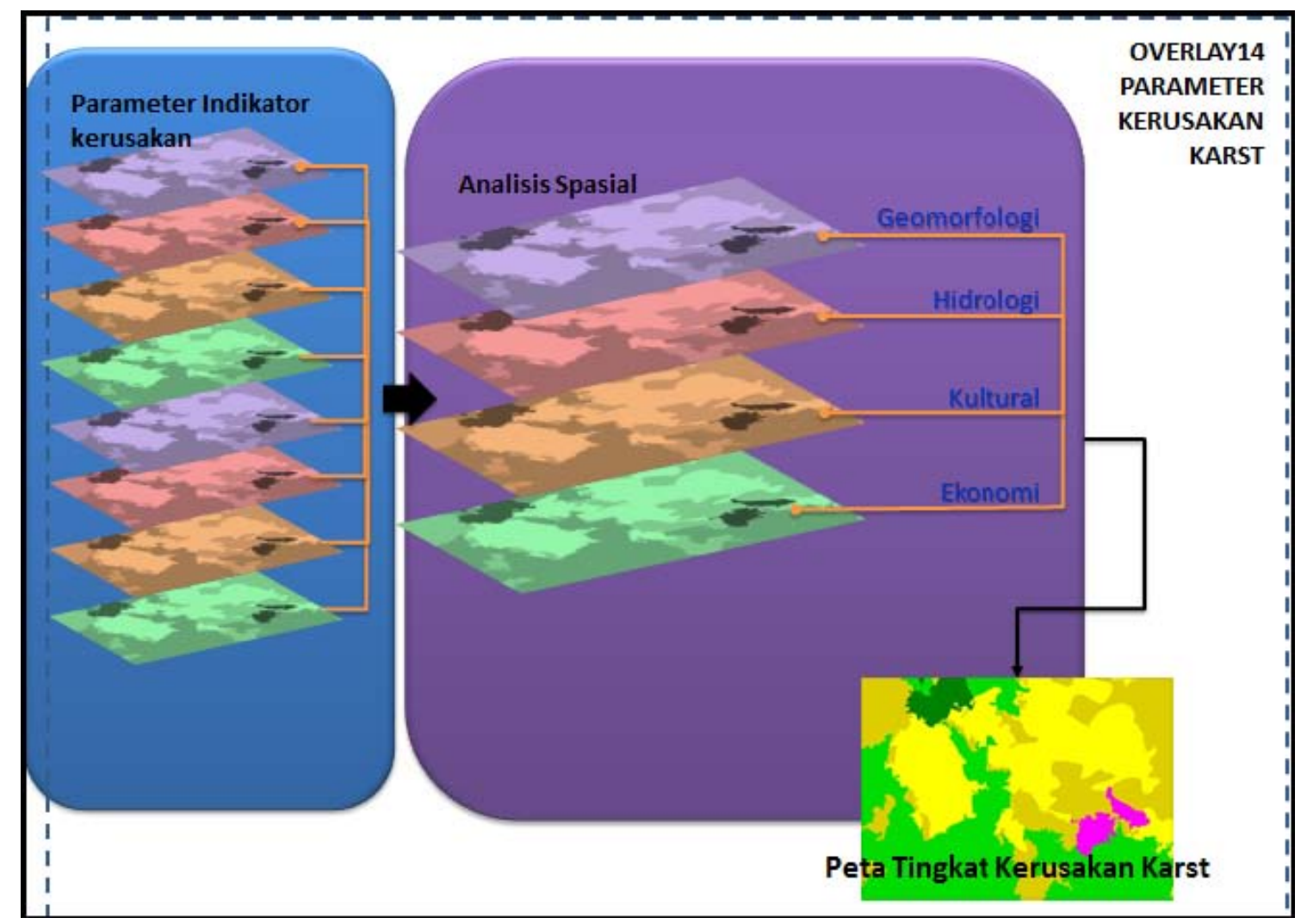

Gambar 1. Skoring Parameter Kerusakan Karst

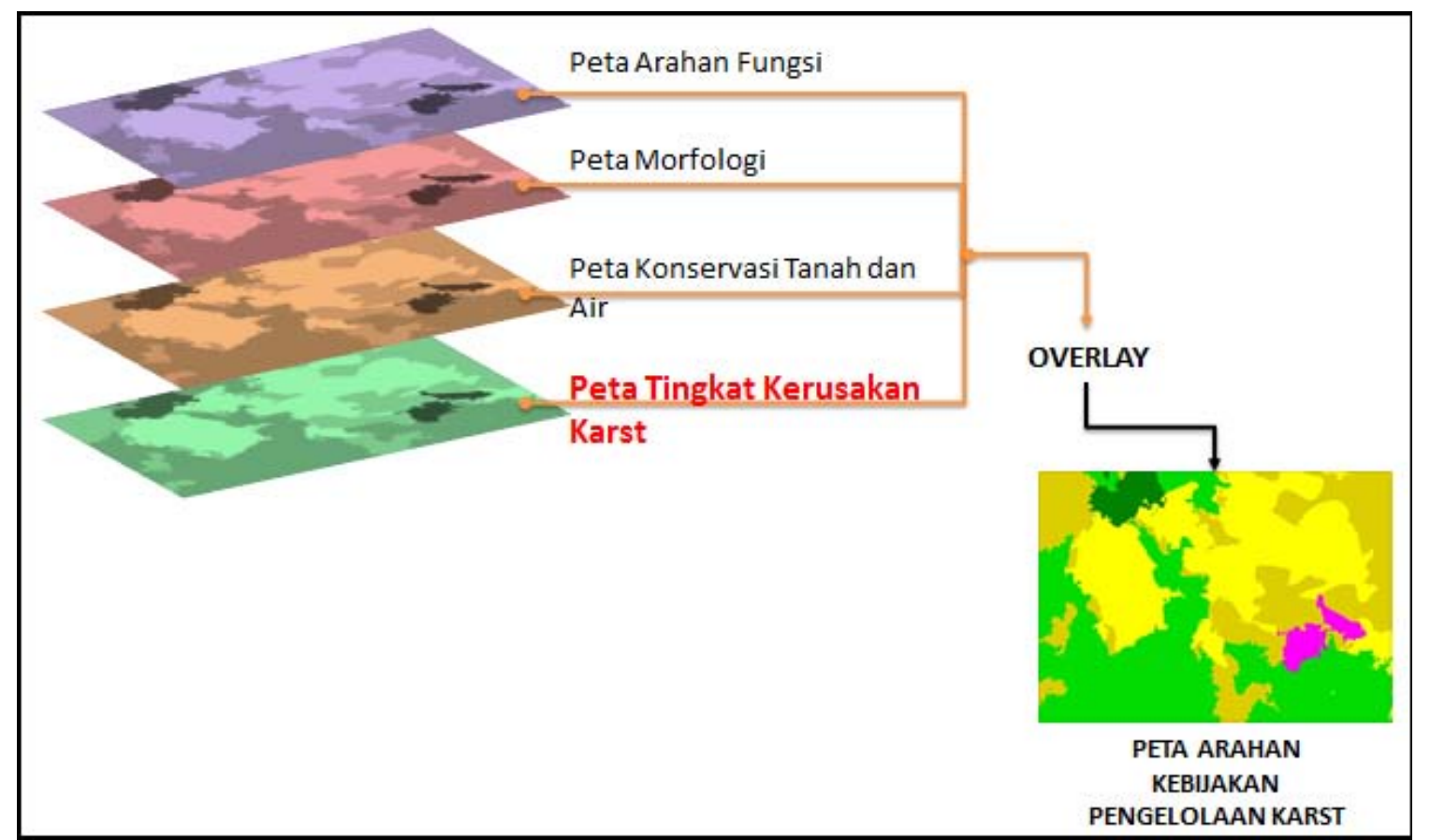

Gambar 2. Tumpang Susun Satuan Unit Strategi Kebijakan Pengelolaan Karst 
Raras Endarto, dkk./ Majalah Geografi Indonesia. 29(1), 2015: 51-59

Tabel 1. Indikator Komponen Bio-Geofisik dan Komponen Sosekbud pada Evaluasi Tingkat Kerusakan Lingkungan Karst

\begin{tabular}{|c|c|c|c|c|c|c|c|c|}
\hline \multirow{2}{*}{ No. } & \multirow{2}{*}{ Kategori } & \multirow{2}{*}{ Atribut } & \multirow{2}{*}{ Indikator } & \multicolumn{4}{|c|}{ Nilai Kerusakan Karst } & \multirow{2}{*}{ Perolehan Data } \\
\hline & & & & 3 & 2 & 1 & 0 & \\
\hline \multirow[t]{3}{*}{ I } & Geomorfologi & $\begin{array}{l}\text { Bentuklahan } \\
\text { Permukaan }\end{array}$ & $\begin{array}{l}\text { 1. Perubahan Morfologi } \\
\text { Akibat Penambangan }\end{array}$ & $>50 \%$ & $30-50 \%$ & $10-30 \%$ & $<10 \%$ & $\begin{array}{l}\text { Sekunder (Interpretasi } \\
\text { citra) }\end{array}$ \\
\hline & & & $\begin{array}{l}\text { 2. Outlet Cekungan } \\
\text { tertutup }\end{array}$ & $\begin{array}{l}\text { Sungai } \\
\text { masuk }\end{array}$ & Ponor/Luweng & $\begin{array}{l}\text { Cekungan } \\
\text { tanpa ponor } \\
\text { dan tanpa telaga }\end{array}$ & Telaga & $\begin{array}{l}\text { Sekunder (Interpretasi } \\
\text { citra) }\end{array}$ \\
\hline & & Tanah & 3. Tutupan Vegetasi & $\begin{array}{l}\text { Tidak } \\
\text { dijumpai }\end{array}$ & $\begin{array}{l}\text { Tutupan vegetasi } \\
<50 \%\end{array}$ & $\begin{array}{l}\text { Tutupan } \\
\text { vegetasi } 50-75 \%\end{array}$ & $\begin{array}{l}\text { Tutupan } \\
\text { vegetasi }>75 \%\end{array}$ & $\begin{array}{l}\text { Sekunder (Interpretasi } \\
\text { citra) Pendekatan Tutupan } \\
\text { Lahan }\end{array}$ \\
\hline II & Hidrologi & Kuatitas Air & $\begin{array}{l}\text { 4. Kondisi mataair } \\
\text { 5. Keberadaan Air pada } \\
\text { Gua }\end{array}$ & $\begin{array}{l}\text { Kering } \\
\text { Kering }\end{array}$ & $\begin{array}{l}\text { Berkurang } \\
\text { Basah }\end{array}$ & $\begin{array}{l}\text { Stabil } \\
\text { Beraair Periodik }\end{array}$ & $\begin{array}{l}\text { Meningkat } \\
\text { Berair } \\
\text { sepanjang } \\
\text { tahun }\end{array}$ & $\begin{array}{l}\text { Primer } \\
\text { Primer }\end{array}$ \\
\hline III & Kultural/Ekonomi & $\begin{array}{l}\text { Tata Infrastruktur } \\
\text { Bangunan }\end{array}$ & $\begin{array}{l}\text { 6. Bangunan di atas } \\
\text { permukaan karst }\end{array}$ & $>50 \%$ & $40-50 \%$ & $30-40 \%$ & $<30 \%$ & Sekunder \\
\hline
\end{tabular}




\section{HASIL DAN PEMBAHASAN}

Konfigurasi DAS Bribin Hulu

Kawasan karst Gunung Sewu yang didalamnya terdapat beberapa DAS dan diantaranya adalah DAS Bribin yang memiliki keunikan dan potensi sumberdaya air tersendiri. Identifikasi pada sekitar catchment di telaga Sawah Ombo Kelurahan Tambakromo sebagai punyuplai penting dan awal aliran sungai bawah tanah Bribin (Gambar 3). Mempertimbangkan telaga Sawah Ombo dan sekitarnya menyuplai sungai bawah tanah airtanah Bribin menjadikan daerah yang menjadi cacthment telaga Sawah Ombo sebagai fokus daerah kajian. Disamping telaga Sawah Ombo, daerah yang berada disekitar aliran sungai bawah tanah harus dikaji lebih mendalam.

\section{Identifikasi SubDAS Sebagai Satuan Unit Pemetaan}

DAS Bribin hulu memiliki konfigurasi yang sangat unik, dengan dijumpainya aliran permukaan pada sisi utara, kemudian hilangnya aliran permukaan yang berubah menjadi aliran bawah tanah di sisi selatan. Sisi utara yang masih dapat dijumpai aliran permukaan pada terminologi karst disebut cekungan terbuka, dan disebut cekungan tertutup bila tidak dijumpai adanya aliran permukaan (Gambar 4).

Keberadaan cekungan terbuka dan cekungan tertutup pada prinsipnya merupakan satuan klasifikasi Daerah Aliran Sungai (DAS) yang lazim disebut SubDAS. Pengelolaan berbasis sumberdaya air erat kaitannya dengan suplai imbuhan air pada suatu media/ satuan tertentu. Salah satu satuan kajian mengenai pengelolaan sumberdaya adalah dengan menggunakan subDAS-subDAS sebagai satuan unit pemetaan. Melalui identifikasi karakteristik dan keberadaan subDAS diharapkan dapat memberikan representasi informasi dan upaya lebih lanjut terkait pengelolaan lingkungan.

\section{Karakteristik Karst DAS Bribin Hulu}

DAS Bribin yang sebagai bagian dari Karst Gunungsewu, merupakan salah satu kenampakan karst yang paling termahsyur dari Indonesia di mata dunia. Kawasan karst Gunungsewu merupakan kawasan dengan tahap perkembangan dewasa (Haryono, 2008). Berdasarkan hasil lapangan dan data skunder yang ada dapat diketahui bahwa terdapat sebaran kenampakan karst yang cukup rapat di kawasan studi. Sesuai dengan tahap perkembangannya, di kawasan penelitian banyak dijumpai cekungan-cekungan tertutup (doline), sistem aliran multi-basinal, kegelkarst (bukit kerucut karst), karren, sistem drainase bawah permukaan, sinkhole berupa luweng atau ponor, dan gua.

Identifikasi karakteristik karst bagian hulu DAS Bribin juga dijumpai Konfigurasi bentuklahan unik, yaitu merupakan bentuklahan vulkanik tua (panggung massive), dan disisi selatan adalah bentuklahan asal proses solusional. Kedua jenis asal proses tersebut memiliki karakteristik yang berbeda. Suplai air telaga Sawah Ombo berasal dari bentuklahan vulkanik tua di bagian atasnya.

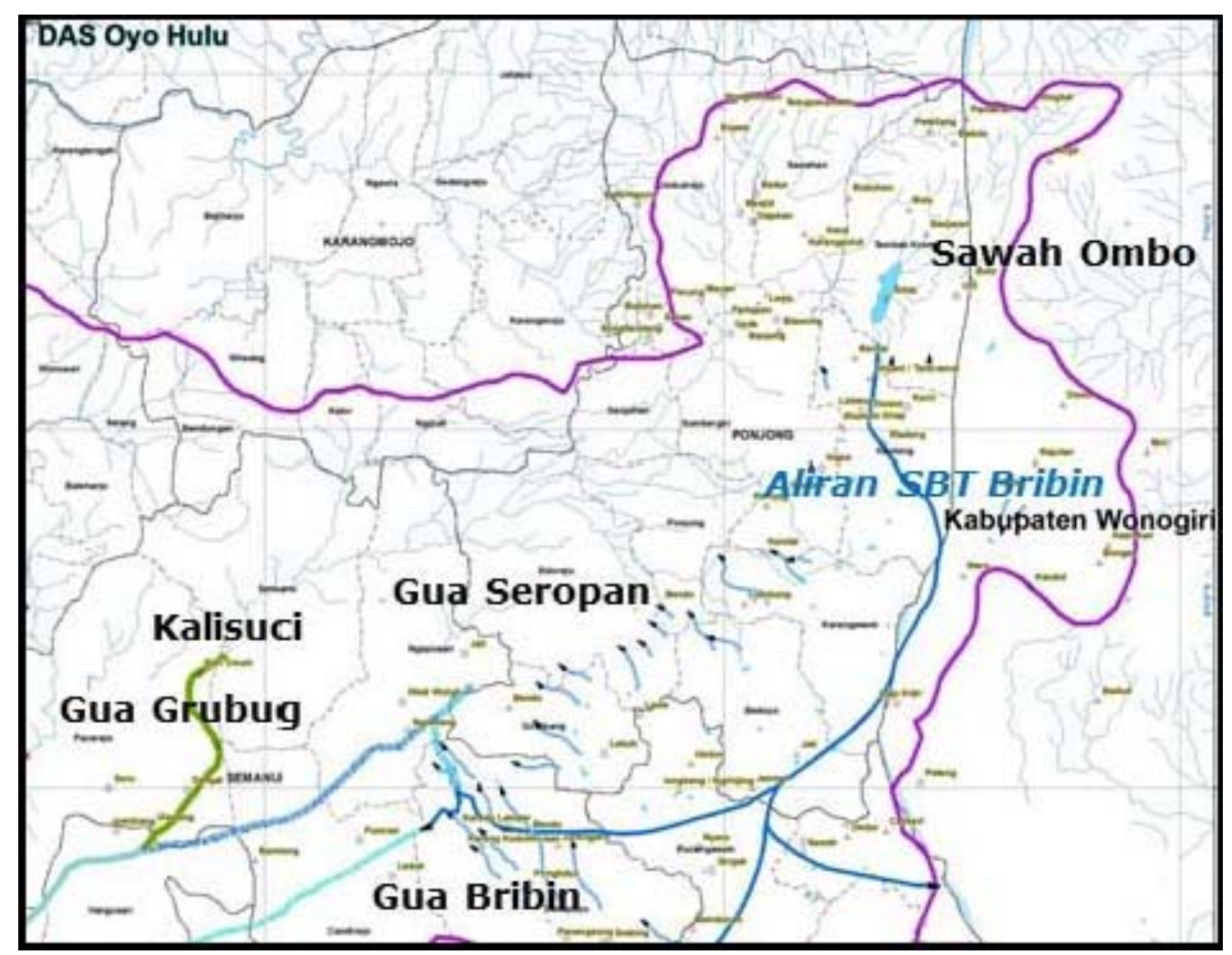

Gambar 3. Telaga Sawah Ombo dan Aliran Sungai Bawah Tanah Bribin 

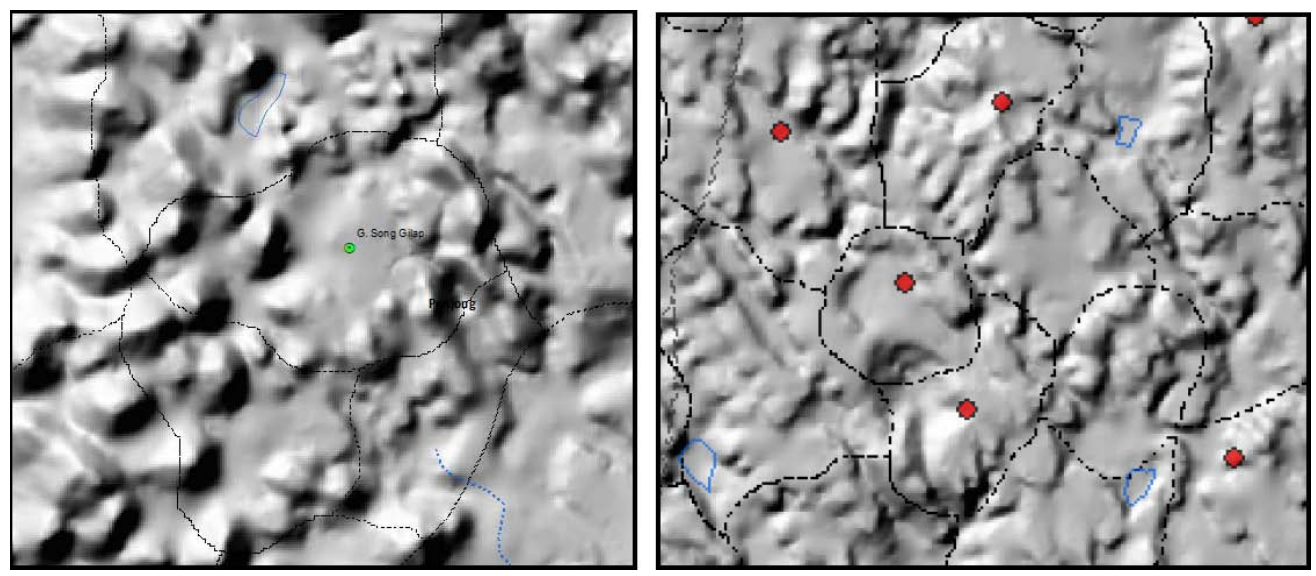

Gambar 4. Cekungan Tertutup yang Membatasi Gua/ Luweng (Kanan), dan

Cekungan Tertutup yang Membatasi Ponor (Kiri. Digunakan Sebagai Satuan Pemetaan (SubDas)

\section{Tingkat Kerusakan Karst DAS Bribin Hulu}

Nilai kerusakan yang paling rendah berdasarkan perhitungan adalah nilai angka 2, sedangkan nilai kerusakan tertinggi 15. Melalui pembagian kelas kerusakan menggunakan natural break diperoleh penilaian skor klas sangat rendah $2-5$, rendah $5,1-8$, sedang $8,1-11$, tinggi $11,1-14$, dan sangat tinggi 14,1 - 17. Tingkat kerusakan dengan membagi 5 kelas kerusakan untuk memudahkan dalam merencanakan arahan strategi pengelolaan karst (Tabel 2).

Tingkat kerusakan karst sangat tinggi memiliki luas 922,27 Ha, adapun secara administrasi lokasi paling luas kerusakan yang termasuk kriteria sangat tinggi di Desa Kenteng, Desa Bedoyo, dan Desa Karangasem. Kedua desa ini memiliki tingkat kerusakan yang sangat tinggi dikarenakan beberapa faktor yang memiliki tingkat kerusakan sangat tinggi berada ada di kedua desa tersebut. Faktor kerusakan yang memacu kondisi kerusakan karst yang sangat tinggi di kedua desa ini adalah parameter perubahan morfologi akibat pertambangan, kondisi mataair, dan bangunan permukiman diatas kawasan karst.

Kerusakan tinggi berada hampir diseluruh desa di wilayah kajian dan merupakan kalsifikasi kerusakan paling luas bila dibandingkan dengan kelas lainnya (9.424,24 Ha). Desa yang memiliki kelas kerusakan tinggi paling luas adalah di Desa Sumbergiri, Desa Ponjong, dan Desa Sawahan Kecamatan Ponjong. Hasil pengematan lapangan di Desa Sumbergiri secara keseluruhan pada dasarnya tidak memiliki kondisi kerusakan yang sangat jelas, namun terdapat indikasi kerusakan terhadap parameter terkait hidrologi. Dijumpainya mataair yang mati pada musim kemarau (Mataair Sulu), adanya outlet cekungan yang mengalir ke sungai, dan perkembangan permukiman yang mengalami peningkatan yang terlihat cukup signifikan.

\section{Strategi Kebijakan Pengelolaan Akibat Kerusakan Karst}

Strategi kebijakan pengelolaan karst dilakukan dengan berbasis karakteristik karst dan berbasis kewilayahan. Strategi kebijakan pengelolan karst berbasis karakteristik karst ditekan pada kenampakan permukaan (eksokarst). Pengelolaan mataair, telaga, gua, dan bukit karst menjadi upaya penting dalam pengelolaan sumberdaya air. Pengelolaan sumberdaya air erat kaitannya dengan keberadaan komponen karst (eksokarst).

Mengacu pada klasifikasi tingkat kerusakan karst, strategi pengelolaan pada eksokarst harus dilakukan. Secara keseluruhan bentukan eksokarst dibagi menjadi dua tipe kenampakan. Bentukan dan fungsi telaga sebagaimana termasuk dalam bentukan eksokarst memiliki fungsi terhadap sumberdaya air harus dijaga kelestariannya. Telaga berfungsi sebagai penyuplai sungai bawah tanah dan mataair yang berada di bawahnya. Salah satu telaga yang menjadi penyuplai pada sungai bawah tanah di DAS Bribin Hulu adalah Telaga Sawah Ombo.

Keberadaan telaga yang berada di bagian hulu dan sebagai penampung air permukaan dari perbukitan vulkanik panggung massive sangat strategis. Telaga Sawah Ombo memiliki tingkat kerawanan sedang harus segera dilakukan penangan pengelolaan. Upaya yang perlu dilakukan pada telaga yang memiliki tingkat kerusakan sedang adalah dengan melakukan tindakan konservasi, diantaranya adalah kerja bakti bersih-bersih telaga, larangan beraktivitas yang dapat mengganggu kelestariaan telaga (Tabel 3).

Strategi kebijakan pengelolaan karst berbasis kewilayahan merupakan rencana pengelolaan kawasan karst secara menyeluruh. Pengelolaan berbasis kewilayahan mempertimbangkan beberapa faktor, diantaranya adalah keberadaannya (morfologi), konservasi kehutanan, dan arahan peruntukan fungsi. Hasil penilaian tingkat kerusakan karst yang diklasifikasikan menjadi 5 kelas kerusakan dimasukan dalam faktor strategi kebijakan pengelolaan berbasis kewilayahan.

Mempertimbangkan adanya morfologi, konservasi kehutanan, dan arahan peruntukan fungsi yang juga 
berbeda, serta tingkat kerusakan karst, diperlukan pemrosesan tumpang susun (overlay) beberapa parameter. Strategi pengelolaan pada klasifikasi kelas kerusakan sangat rendah pada morfologi hulu dan lindung berbeda bila memiliki kerusakan sangat tinggi sama-sama di morfologi hulu dan fungsi lindung. Hal tersebut berlaku pula pada kondisi yang berbeda satu sama yang lain.

Peningkatan peran serta dalam menjaga karst pada karst yang memiliki kerusakan sangat rendah. Peningkatan kesadaran masyarakat melalui sosialisasi dan pendidikan publik pada karst yang memiliki kerusakan karst rendah. Penguatan dan perbaikan peran masyarakat pada kerusakan tingkat sedang. Pembinaan dan pemulihan masyarakat melalui penghijauan pada kerusakan tingkat tinggi. Dan Pemulihan prioritas I kawasan lindung dan II kawasan penyangga melalui konservasi vegetatif dan sipil teknis.

Tingkat kerusakan lingkungan rendah di kawasan penyangga dan konservasi agroforestri dengan mempertimbangkan bentanglahan sekitar dapat dilakukan upaya konservasi teknik vegetatif. Upaya konservasi vegetatif di kawasan lindung dengan kerusakan karst tinggi merupakan kegiatan penanaman tanaman keras dan tepat guna sehingga dapat diperoleh fungsi lahan (catchment).

Upaya konservasi pada tingkat kerusakan lingkungan karst klas sedang dapat dilakukan dengan konservasi sipil teknis. Pelaksanaan konservasi sipil teknis membutuhkan dukungan materiil yang cukup tinggi. Diperlukan pertimbangan yang komprehensif dalam pelaksanaannya. Upaya teknik ini sangat diperlukan mengingat dampak degradasi lingkungan akan semakin nyata apabila tidak dilaksanakan secepat mungkin. Klasifikasi tingkat kerusakan lingkungan karst klas tinggi membutuhkan penanganan konservasi gabungan antara teknik vegetatif dan sipil teknis.

\section{KESIMPULAN}

1. Karakteristik Karst di DAS Bribin Hulu yang memiliki peranan penting dalam keberlanjutan sumberdaya air yang lestari meliputi:

(a) Telaga Sawah Ombo merupakan penyuplai penting dan sebagai awal terbentuknya sungai bawah tanah Bribin. Pengelolaan pada daerah tangkapan air telaga dan sekitar aliran sungai bawah tanah Bribin menjadi urgensi guna tercapainya sumberdaya air yang lestari;

Tabel 2. Tingkat Kerusakan Karst di DAS Bribin Hulu tiap Desa

\begin{tabular}{|c|c|c|c|c|c|c|c|}
\hline Kecamatan & Desa & Sangat Rendah & Rendah & Sedang & Tinggi & Sangat Tinggi & Luas (Ha) \\
\hline \multirow{4}{*}{ Eromoko } & Basuhan & 109,7 & 275,49 & 540,31 & 10,63 & 27,33 & 963,46 \\
\hline & Ngandong & & & 31,53 & 413,75 & & 445,28 \\
\hline & Pasekan & & & 23,07 & 155,76 & & 178,83 \\
\hline & Pucung & & 93,47 & 662,79 & & & 756,27 \\
\hline \multirow[t]{4}{*}{ Karangmojo } & Bendungan & & & & 4,05 & & 4,05 \\
\hline & Gedang Rejo & & & & 211,59 & & 211,59 \\
\hline & Kelor & & & & 352,9 & & 352,9 \\
\hline & Wiladeg & & & & 191,63 & & 191,63 \\
\hline \multirow[t]{11}{*}{ Ponjong } & Bedoyo & 52 & 92,64 & 149,4 & 326,04 & 3,09 & 623,18 \\
\hline & Genjahan & & & & 360,75 & & 360,75 \\
\hline & Gombang & & & 81,65 & 181,92 & 34,79 & 298,36 \\
\hline & Karang Asem & 9,56 & 36,82 & 55,84 & 427,14 & 346,94 & 876,3 \\
\hline & Kenteng & 0,06 & 8,84 & 163,12 & 388,45 & 367,18 & 927,64 \\
\hline & Ponjong & & 14,71 & & 605,67 & & 620,38 \\
\hline & Sawahan & & & 425,9 & 386,6 & & 812,5 \\
\hline & Sidorejo & 36,94 & 107,51 & 468,4 & 761,48 & 82,37 & 1456,7 \\
\hline & Sumber Giri & & 38,59 & 29 & 1152,24 & 0 & 1219,83 \\
\hline & Tambakromo & & & 395,96 & 814,3 & & 1210,26 \\
\hline & Umbul Rejo & & & & 732,09 & & 732,09 \\
\hline \multirow[t]{2}{*}{ Pracimantoro } & Glinggang & 90,75 & 11,91 & & 96,85 & 2,03 & 201,53 \\
\hline & Wonodadi & & 57,57 & 8,36 & & & 65,93 \\
\hline Rongkop & Pucanganom & & & 106,86 & 64,68 & & 171,54 \\
\hline \multirow[t]{3}{*}{ Semanu } & Ngeposari & & & 53,77 & 709,1 & 58,55 & 821,42 \\
\hline & Pacarejo & & & & 20,57 & & 20,57 \\
\hline & Semanu & & & & 1056,03 & & 1056,03 \\
\hline Semin & Pundung Sari & & & 12,12 & & & 12,12 \\
\hline Luas (Ha) & & 299,01 & 737,54 & 3208,09 & 9424,24 & 922,27 & 14591,15 \\
\hline
\end{tabular}


Tabel 3. Strategi Pengelolaan Lingkungan Berbasis

\begin{tabular}{|c|c|c|c|c|c|}
\hline \multirow{2}{*}{ Eksokarst } & \multirow[b]{2}{*}{ Sangat Rendah } & \multicolumn{4}{|c|}{ Tingkat Kerusakan Karst } \\
\hline & & Rendah & Sedang & Tinggi & Sangat Tinggi \\
\hline Mataair & $\begin{array}{l}\text { Menjaga tutupan vegetasi pada } \\
\text { daerah tangkapan air indikatif }\end{array}$ & $\begin{array}{l}\text { Melakukan penanaman } \\
\text { pohon pada daerah } \\
\text { tangkapan air indikatif yang } \\
\text { gersang/tandus }\end{array}$ & $\begin{array}{l}\text { Melakukan Penghijauan } \\
\text { secara massive pada } \\
\text { daerah tangkapan } \\
\text { indikatif }\end{array}$ & $\begin{array}{l}\text { Melakukan Penghijauan secara } \\
\text { massive, dan upaya sipil teknis } \\
\text { untuk meningkatkan imbuhan } \\
\text { airtanah (pembuatan } \\
\text { checkdam, talud, dan lainnya) } \\
\text { pada daerah tangkapan } \\
\text { indikatif }\end{array}$ & $\begin{array}{l}\text { Melakukan Penghijauan secara } \\
\text { massive, dan upaya sipil teknis } \\
\text { untuk meningkatkan imbuhan } \\
\text { airtanah (pembuatan } \\
\text { checkdam, talud, dan lainnya) } \\
\text { pada daerah tangkapan } \\
\text { indikatif. Diikuti dengan } 1 . \\
\text { Penegakan aturan terhadap alih } \\
\text { fungsi lahan, 2. Pengupayaan } \\
\text { perubahan status budidaya } \\
\text { menjadi lindung pada daerah } \\
\text { tangkapan indikatif }\end{array}$ \\
\hline Telaga & $\begin{array}{l}\text { Menjaga keberlangsungan } \\
\text { genangan }\end{array}$ & $\begin{array}{l}\text { Melakukan tindakan } \\
\text { konservasi (kerja bakti } \\
\text { kebersihan telaga) }\end{array}$ & $\begin{array}{l}\text { Melakukan tindakan } \\
\text { konservasi (kerja bakti } \\
\text { kebersihan telaga, } \\
\text { larangan beraktivitas } \\
\text { yang dapat mengganggu } \\
\text { kelestarian telaga) }\end{array}$ & $\begin{array}{l}\text { Penghijauan di daerah yang } \\
\text { menyuplai telaga }\end{array}$ & $\begin{array}{l}\text { Penghijauan di daerah yang } \\
\text { menyuplai telaga dan } \\
\text { pembuatan bangunan sipil } \\
\text { teknis untuk mempercepat } \\
\text { aliran permukaan masuk ke } \\
\text { telaga }\end{array}$ \\
\hline Gua & $\begin{array}{l}\text { Menjaga keberadaan dan } \\
\text { kelestarian gua }\end{array}$ & $\begin{array}{l}\text { Melakukan tindakan } \\
\text { konservasi (kerja bakti } \\
\text { kebersihan gua) }\end{array}$ & $\begin{array}{l}\text { Melakukan tindakan } \\
\text { konservasi (kerja bakti } \\
\text { kebersihan telaga, } \\
\text { larangan beraktivitas } \\
\text { yang dapat mengganggu } \\
\text { kelestarian gua) }\end{array}$ & $\begin{array}{l}\text { Pelarangan segala bentuk } \\
\text { aktivitas di dalam gua }\end{array}$ & $\begin{array}{l}\text { Pelarangan segala bentuk } \\
\text { aktivitas di dalam gua, } \\
\text { pembuatan media hidup } \\
\text { (habitat) untuk } \\
\text { berkembangnya kembali satwa } \\
\text { gua }\end{array}$ \\
\hline Bukit Karst & $\begin{array}{l}\text { Menjaga tutupan vegetasi pada } \\
\text { bukit-bukit karst }\end{array}$ & $\begin{array}{l}\text { Melakukan penanaman } \\
\text { pohon pada bukit-bukit karst } \\
\text { yang gersang/tandus }\end{array}$ & $\begin{array}{l}\text { Melakukan Penghijauan } \\
\text { secara massive pada } \\
\text { daerah tangkapan } \\
\text { indikatif }\end{array}$ & $\begin{array}{l}\text { Pemberian stimulus guna } \\
\text { berkembangnya vegetasi } \\
\text { (pupuk kompos, pupuk an } \\
\text { organik yang ramah } \\
\text { lingkungan }\end{array}$ & $\begin{array}{l}\text { Penegakan aturan dan hukup } \\
\text { terhadap berubahnya kondisi } \\
\text { bukit, dan dilakukan upaya } \\
\text { reklamasi vegetatif dan sipil } \\
\text { teknis }\end{array}$ \\
\hline
\end{tabular}


(b) Konfigurasi bentuklahan unik, yaitu merupakan bentuklahan vulkanik tua (panggung massive), dan disisi selatan adalah bentuklahan asal proses solusional. Kedua jenis asal proses tersebut memiliki karakteristik yang berbeda;

2. Tingkat kerusakan karst sangat tinggi secara administratif paling luas meliputi Desa Karangasem, Desa Bedoyo, dan Desa Kenteng (922,27 Ha), adapun kriteria klas tinggi berada di Desa Sumbergiri, Desa Ponjong, Desa Sawahan (9.424,24 Ha);

3. Strategi kebijakan pengelolaan karst dilakukan dengan berbasis karakteristik karst dan berbasis kewilayahan, meliputi sebagai berikut:

(a) Strategi kebijakan pengelolan karst berbasis karakteristik karst ditekan pada kenampakan permukaan (eksokart). Strategi kebijakan pengelolaan karst berbasis kewilayahan merupakan rencana pengelolaan kawasan karst secara menyeluruh;

(b) Pengelolaan berbasis kewilayahan mempertimbangkan beberapa faktor, diantaranya adalah keberadaannya (morfologi), konservasi kehutanan, dan arahan peruntukan fungsi.

\section{DAFTAR PUSTAKA}

Adji, T.N., (2010). Variasi Spasial-Temporal Hidrogeokimia Dan Sifat Aliran Untuk Karakter Sistem Karst Dinamis Di Sungai Bribin Kabupaten Gunungkidul Yogyakarta. Desertasi. Yogyakarta. Program Pasca Sarjana UGM.

Ford, D dan William P.W. (2007). Karst Hydrogeology And Geomorphology. Chicester. John Willey and Sons

Gunawan, T. (1997). The Contribution of Aerial Photograps in Evaluation of Bribin Catchment Area, Gunung Kidul, Yogyakarta, Indonesia. The Indonesian Journal of Geography. 29 (73), 49-65.

Gunawan, T. (2012). Kontribusi Citra Penginderaan Jauh untuk Kajian Perubahan Fenomena Hidrologi Pasca Letusan Gunungapi Merapi Sebagai Dasar Konservasi Lingkungan. Kasus di Wilayah Kecamatan Cangkringan, Sleman, Yogyakarta. Laporan Penelitian. Hibah Penelitian Fakultas Geografi UGM. Nomor: UGM/GE/1139C-1/M/04/12.

Haryono, E. (2000). Some Properties of Epikarst Drainage System. The Indonesian Journal of Geography. 32 (79/80), 75-86.

Haryono, E. (2001). Nilai Hidrologis bukit Karst, Makalah Seminar Nasional, Eko-Hidrolik, 28-29 Maret 2001. Jurusan Teknik Sipil. UGM
Haryono, E dan Adji, TN. (2004). Pengantar Geomorfologi dan Hidrologi Karst. Yogyakarta. Kelompok Studi Karst Fakultas Geografi Universitas Gadjah Mada.

Haryono, E. \& Day, M. (2004). Landform differentiation within the Gunung kidul kegel karst, Java, Indonesia. Journal of Cave and Karst Studies. 66 (2), 62-69.

Haryono, E. (2008). Model Perkembangan Karst Berdasarkan Morfometri Jaringan Lembah Di Karangbolong, Gunungsewu. Blambangan dan Rengel. Disertasi. Yogyakarta. Fakultas Geografi Universitas Gadjah Mada.

Haryono, E. (2014). Model Penilaian Kerusakan Ekosistem Karst di Indonesia. Laporan Penelitian. Yogyakarta. Fakultas Geografi Universitas Gadjah Mada.

Krothe, N.C. (2003). Groundwater Flow And Contaminant Transport Thought The Epikarst In Two Karst Drainage System. USA.

Klimchouk, A. (1997). The natural and Principal characteristics of epikarst, 12th International Congress of Speleolog. La Chaux-de-Fonds, pp.306.

Knapp, B.J. (1999). Elements of Geographical Hydrology. London. Unwin Hyman Ltd

McDonald and Partners. (1984). The Greater Yogyakarta-Groundwater Resources Study. 3C. Yogyakarta. Cave Survey.

Raharjo, dkk. (1995). Westenschappelijke Mmededeelingen No. 9, In: Formanifera Besar Tersier Indonesia. Yogyakarta. UGM, hal. 1-110.

Santoso, L.W. (2008). Identifikasi Kerusakan Ekosistem di Zona Utara dan Selatan Kabupaten Gunungkidul. Laporan Penelitian. Yogyakarta. Fakultas Geografi UGM

Sudarmadji, Widyastuti, M. Dan Haryono, E. (2005). Pengembangan Metode Konservasi Sungai Bawah Tanah Sistem Bribin-Baron. Laporan Penelitian. Yogyakarta. Hibah Bersaing UGM.

Sweeting. (1972). Karst Landform. Oxford London. MacMilan

Thornbury. (1954). Principle Of Geomorphology. New York. John Wiley and Sons.

Trudgil, S. (1985). Limestone Geomorpholgy. New York. Longman.

Van Zuidam, R. A. (1973). Guide To Geomorphological Photo-Interpretation.

Verstappen H.Th. (1983). Applied Geomorphology "Goemorphological Survey For Environtmental Development". Amsterdam. Elsevier.

Van Beynen, Philip and Townsend, Kaya. (2005). A Disturbance Index For Karst Environments, Florida. University of South Florida. 